\title{
Dilatation of the Ductus Arteriosus by Diazoxide in Fetal and Neonatal Rats
}

\author{
Katsuaki Toyoshima, Kazuo Momma, Tetsuko Ishii, \\ and Toshio Nakanishi
}

\section{Keywords}

Diazoxide $\cdot$ Ductus arteriosus $\cdot$ Rat

\subsection{Background}

We previously reported that ATP-sensitive potassium $\left(\mathrm{K}_{\mathrm{ATP}}\right)$ channels regulate ductal constriction in response to oxygen [1]. Diazoxide is a $\mathrm{K}_{\mathrm{ATP}}$ channel opener while the usefulness of diazoxide for hyperinsulinemic hypoglycemia is well established. Yoshida et al. reported DA reopening in very low-birth-weight infants [2]. The objectives of this study were to elucidate the effect of $\mathrm{K}_{\mathrm{ATP}}$ channel openers on the DA in neonatal rats as well as the different effects in preterm and full-term fetal rats [3].

\subsection{Methods}

Near-term rat pups delivered via a cesarean section were housed at $33{ }^{\circ} \mathrm{C}$. After rapid whole-body freezing, the ductus arteriosus (DA) diameter was measured using a microscope and a micrometer. Full-term pregnant rats (gestational day 21) were

\footnotetext{
K. Toyoshima $(\varangle)$

Division of Pediatric Cardiology, Tokyo Women's Medical University,

Shinjuku, Tokyo, Japan

Division of Neonatology, Kanagawa Children's Medical Center, Yokohama, Kanagawa, Japan e-mail: ktoyoshima@kcmc.jp

K. Momma · T. Ishii · T. Nakanishi

Department of Pediatric Cardiology, Tokyo Women's Medical University,

Tokyo, Japan

e-mail: nakanishi.toshio@twmu.ac.jp
} 
intraperitoneally injected with diazoxide (10 and $100 \mathrm{mg} / \mathrm{kg}$ ) $4 \mathrm{~h}$ before delivery, and the neonatal DA diameter was measured at 0,30 , or $60 \mathrm{~min}$ after birth. The newborn rats were also intraperitoneally injected with diazoxide (10 and $100 \mathrm{mg} /$ $\mathrm{kg}$ ) at birth or $60 \mathrm{~min}$ after birth. DA was measured at 0, 30, or $60 \mathrm{~min}$ after injection. In the fetal study, constricted by COX and NOS inhibition the dilating effects of diazoxide was studied by simultaneous administration of indomethacin $(10 \mathrm{mg} /$ $\mathrm{kg})$ and L-nitroarginine methyl ester $(100 \mathrm{mg} / \mathrm{kg})$ in gestational day 21 and 19.

\subsection{Results}

DA closure was delayed in rats exposed to prenatal diazoxide. Both doses of transplacentally administered diazoxide induced significant and dose-dependent inhibitory effect in postnatal DA constriction. Intraperitoneal injection of diazoxide at 60 min after birth induced DA reopening in a dose-dependent manner.

Diazoxide $(10 \mathrm{mg} / \mathrm{kg})$ dilatated the fetal DA in both near-term and preterm fetal rats. The effect of diazoxide in dilating the DA at preterm was the same as at fullterm fetal rats.

\subsection{Conclusion}

$\mathrm{K}_{\text {АTP }}$ channel openers attenuate postnatal DA constriction and dilatate a closing DA in neonatal rats. If the DA is affected in a similar manner in human neonates, then PDA could be warranted for use with $\mathrm{K}_{\mathrm{ATP}}$ channel openers to treat infants with hyperinsulinemic hypoglycemia, especially preterm infants.

\section{References}

1. Nakanishi T, et al. Mechanisms of oxygen-induced contraction of ductus arteriosus isolated from the fetal rabbit. Circ Res. 1993;72(6):1218-28.

2. Yoshida $\mathrm{K}$, et al. High prevalence of severe circulatory complications with diazoxide in premature infants. Neonatology. 2014;105(3):166-71.

3. Toyoshima K, et al. Dilatation of the ductus arteriosus by diazoxide in fetal and neonatal rats. Pediatr Int. 2017;59(12):1246-51. 
Open Access This chapter is licensed under the terms of the Creative Commons Attribution 4.0 International License (http://creativecommons.org/licenses/by/4.0/), which permits use, sharing, adaptation, distribution and reproduction in any medium or format, as long as you give appropriate credit to the original author(s) and the source, provide a link to the Creative Commons license and indicate if changes were made.

The images or other third party material in this chapter are included in the chapter's Creative Commons license, unless indicated otherwise in a credit line to the material. If material is not included in the chapter's Creative Commons license and your intended use is not permitted by statutory regulation or exceeds the permitted use, you will need to obtain permission directly from the copyright holder. 